\title{
1-Methylcyclopropene maintains postharvest quality in Norwegian apple fruit
}

\author{
N Falagán and LA Terry \\ Plant Science Laboratory, Cranfield University, Cranfield, UK \\ Corresponding author: N Falagán, Cranfield University, College Road, Cranfield MK43 0AL, \\ UK. Email: natalia.falagan@cranfield.ac.uk
}

\begin{abstract}
Norwegian fruit production is mostly destined for the local market and can suffer from poorquality retention during storage. 1-Methylcyclopropene (1-MCP) is an inhibitor of ethylene perception used to maintain the physical and functional quality of pome fruit. Extensive work has been carried out on the effect of 1-MCP on apples, but not on cultivars grown in Norway. In this work, the potential of 1-MCP application $\left(0.625 \mathrm{ml} \mathrm{l}^{-1}\right.$ for $24 \mathrm{~h}$ at $\left.0 \pm 1^{\circ} \mathrm{C}\right)$ for ripening control of the apple cultivars 'Aroma', 'Red Gravenstein', and 'Summered' was studied during 1 and 1.5 months of cold storage; both scenarios were followed by five days of shelf life. The application of 1-MCP reduced softening by an average of $12 \%$ in 'Aroma', 'Red Gravenstein', and 'Summered' apples when cold stored for both 1 and 1.5 months as compared to control. External colour remained similar to initial values in 1-MCP fruit when compared to control apples, which presented a significant skin darkening. This indicated a delay in the ripening process. 1-MCP treatment did not affect total soluble solids content. 'Aroma' samples treated with 1-MCP showed a low sucrose hydrolysis, indicating a slower ripening process. This work confirms that 1-MCP postharvest treatment shows great potential for maintenance of apple cvs. in Norway during cold storage and shelf life.
\end{abstract}

Keywords Malus domestica, food waste, postharvest, quality

\section{INTRODUCTION}

Apples (Malus domestica Borkh) cultivated in Norway have a high initial quality and great market potential. They are highly appreciated by local consumers. The mean annual apple production in Norway (1998-2017) is only 12,660 t (FAOSTAT, 2018) which is mainly destined for the local market. These apples have poor quality retention during storage, with high index of firmness loss and fungal decay incidence.

Postharvest treatments can be applied to enhance local production and its availability. The application of controlled atmosphere (CA) storage is well established for apples, showing beneficial effects on quality retention by delaying ripening and senescence (Brizzolara et al., 2017; Falagán and Terry, 2018; Meberg et al., 2000; Thewes et al., 2017). Apples can be stored up to 12 months under near hypoxic conditions (Watkins, 2003), allowing year-round availability. In Norway, the targeted storage time is 1-2 months as this country's local production is exclusively destined for seasonal consumption. For this reason, the investment in CA storage facilities is not cost-effective when compared to normal cold storage (Kart and Demircan, 2015).

Another option to delay ripening is controlling ethylene (Golding and Singh, 2017). 1Methylcyclopropene (1-MCP) is a gaseous cyclic olefin which binds to ethylene receptors, avoiding ethylene-dependent responses (Almeida et al., 2016; Liguori et al., 2017; Sisler and Serek, 1997). Its effectiveness is extensively proven in many apples cvs. but not in apples grown in Norway, which could benefit from the ripening control action of 1-MCP (Gwanpua et al., 2017; Lee et al., 2016; Watkins and Nock, 2012; Watkins et al., 2000). 1-MCP was approved by the US Environmental Protection Agency for ornamental products in 1999 and for edible food products in 2002. Then, it was registered as Generally Recognised As Safe 
active ingredient by the FDA (2004). By 2011, around 50 countries had approved the use of 1MCP for fresh produce and there are currently five registered products that contain this active ingredient such as SmartFresh ${ }^{\mathrm{TM}}$ and EthylBlock ${ }^{\mathrm{TM}}$ by AgroFresh Inc. (Rademacher, 2015). In the European Union, the active ingredient 1-MCP is included in Annex I of the Directive 91/414/EEC (2005), allowing its use on fruits including apples. 1-MCP is a good alternative or supplement to CA storage because it can maintain fruit physical and functional quality across the supply chain (Blankenship and Dole, 2003; Golding and Singh, 2017; Watkins and Nock, 2012). The application of 1-MCP is straight forward, innocuous for the operator and facilities, and economical (Watkins, 2006). It should be applied along with cold storage practices, and preferably right after harvest. Its effectiveness on apple is mainly influenced both by the maturity stage of the fruit at harvest, and cultivar (cv.; Watkins, 2006). The main benefit of 1MCP for apples is the reduction of major physiological storage disorders (Watkins et al., 2000) and firmness loss (Moran and McManus, 2005).

The aim of the work was to examine the potential of 1-MCP for control of ripening in the apple cvs.: 'Aroma', 'Red Gravenstein', and 'Summered', cultivated in Norway.

\section{MATERIALS AND METHODS}

Plant material

Apple cvs. 'Aroma', 'Red Gravenstein', and 'Summered' were harvested at commercial maturity from Sletthagen (5778 Utne, Norway) on 15 October 2018. Maturity was assessed by experienced local farm staff based on fruit appearance (i.e. size, skin colour, firmness). The samples were shipped by air on 16 October 2018, from Oslo (Norway) to the Plant Science Laboratory at Cranfield University (UK) under cold conditions $\left(\sim 0^{\circ} \mathrm{C}\right)$. The apples were immediately placed in the treatment boxes in a cold room at $0 \pm 1^{\circ} \mathrm{C}$ and $90 \pm 5 \%$ relative humidity (RH).

\section{Experimental design}

Apples of each cv. were placed in 3001 hermetically sealed boxes equipped with an inlet and outlet bulkhead fitting connected to an air supply system which recirculated the atmosphere inside the container. Two groups were considered: control (non-treated) and 1-MCP (AgroFresh ${ }^{\mathrm{TM}}, \mathrm{UK}$ ), exposed to $0.625 \mathrm{ml} \mathrm{l}^{-1}$ for $24 \mathrm{~h}$ at $0 \pm 1^{\circ} \mathrm{C}$ (Chope et al., 2007). The apples were stored at $0 \pm 1{ }^{\circ} \mathrm{C}$ and $90 \pm 5 \% \mathrm{RH}$ for one month followed by five days at $20^{\circ} \mathrm{C}$ simulating shelf life (Scenario 1), and 1.5 months at $0 \pm 1{ }^{\circ} \mathrm{C}$ and $90 \pm 5 \% \mathrm{RH}$ followed by five days at $20^{\circ} \mathrm{C}$ simulating shelf life (Scenario 2). Three biological replicates, consisting of six apples each, were analysed at each sampling point: day 0 - baseline; day 30 - after one month of cold storage; day 35 - after Scenario 1 shelf life (shelf life 1 - SL1); day 45 - after 1.5 months of cold storage; and day 50 - after Scenario 2 shelf life (shelf life 2 - SL2). Samples from each cv. were snap-frozen and freeze dried at each evaluation date. Samples were kept at $-80^{\circ} \mathrm{C}$ until analysis.

\section{Firmness}

Firmness was measured with a uniaxial testing machine (Instron 5542, Instron, Bucks., UK). A $10 \mathrm{~mm}$ diameter probe was used at $240 \mathrm{~mm}$ min 1 crosshead speed and $8 \mathrm{~mm}$ penetration depth, according to Anastasiadi et al. (2017). Results were expressed as Newton (N).

\section{Colour}

For each replicate, six apples were placed in a photoE-Box plus 1419 (Ortech Professional Lighting, CA, USA). White fluorescent light (D65) was used on the sides and underneath the fruit. An exposure of $62 \mathrm{~ms}$, intensity of 155, gain of 0.9 , and gamma of 1 were applied. Absorption spectrum was recorded and analysed using a Lumenera Infinity3-6UR camera 
(Lumenera corporation, Ottawa, Canada) and the Infinity Analyse application package. Although measurements of $\mathrm{L}^{*}, \mathrm{a}^{*}$, and $\mathrm{b}^{*}$; chroma; and hue angle $\left(\mathrm{H}^{\circ}\right)$ were recorded, we herein reported $\mathrm{H}^{\circ}$ as it best represents the colour change between green and red $\left(\mathrm{H}^{\circ}=1 / 4 \tan ^{-1}\right.$ [b*/a*]; Duarte et al., 2009).

\section{Total soluble solids}

Total soluble solids were determined using a digital refractometer (model PR-32a, Atago Ltd, Tokyo, Japan). Results were expressed as ${ }^{\circ}$ Brix.

\section{Non-structural carbohydrates}

For each replicate, freeze-dried apple powder $(150 \mathrm{mg})$ was extracted according to Downes and Terry (2010) with slight modifications. Skin and flesh were analysed separately. An HPLC (Agilent Technologies 1200 series, Berks., UK) with an evaporative light scattering detector (Agilent Technologies 1200 Series, G1362A) was used to quantify sugar extracts $(20 \mathrm{ml})$. Elution was performed at $1 \mathrm{ml} \mathrm{min}^{-1}$ flow rate, at $30^{\circ} \mathrm{C}$, as follows: $80 \% \mathrm{~B}$ at $0 \mathrm{~min}, 50 \%$ at 15 $\mathrm{min}, 50 \%$ at $18 \mathrm{~min}$, and $80 \%$ at $20 \mathrm{~min}$. Sugars were quantified using the external standards: glucose, fructose, and sucrose purchased from Sigma-Aldrich.

\section{Statistical analysis}

Data were subjected to analysis of variance using GenStat for Windows (8.1, VSN International Ltd, Herts., UK). The differences between cvs., treatments, and storage time were studied. Least significant difference $($ LSD) values $(p<0.05)$ were calculated from each analysis.

\section{RESULTS AND DISCUSSION}

Meeting consumer demands is key to introducing new cvs. in the market (Silvestri et al., 2018). In the case of apples, it is the taste (i.e. sweetness, texture, mouth-feel attributes) and/or appearance (i.e. external fruit colour, defects), which drives consumer choice (Chen et al., 2017; Pre-Aymard et al., 2005). The marketability of the three main apple cvs. grown in Norway quickly declines after harvest, as they lose their firmness, negatively impacting on their quality. This process critically reduces the consumer acceptability.

Investing in CA facilities is not ideal as, in this case, the aimed storage period is short (1-2 months). In this study, 1-MCP treatment was applied to maintain the initial quality of apples cultivated in Norway by delaying ripening. Apple firmness is broadly used as a ripening and 'condition' indicator. The consumer considers that around $50 \mathrm{~N}$ is the best eating firmness level for apple fruit (Hoehn et al., 2003). 'Red Gravenstein' apples showed the highest initial firmness $(\sim 45 \mathrm{~N})$ when compared to 'Aroma' and 'Summered' cvs. $(\sim 35 \mathrm{~N})$. In all cases the values were lower than the firmness at harvest of other well-known cvs. such as 'Royal Gala' which is generally picked at $65-70 \mathrm{~N}$ (Schwallier, 2012). For this reason, maintaining the values registered at harvest is fundamental to stay close to the $50 \mathrm{~N}$ consumers' requirements. The firmness values at day 0 were better maintained in fruit subjected to 1-MCP treatment compared to control fruit in both scenarios. Specifically, 'Aroma' apples treated with 1-MCP showed no loss in firmness after 1 or 1.5 months of cold storage, while control 'Aroma' apples lost ca. $10 \%$ of their initial firmness after one month of cold storage and $9.22 \%$ after 1.5 months. Similar results were obtained for 'Red Gravenstein' and 'Summered' cvs. (Figures 1 and 2). Apple softening is related to the disassembly of the cell wall components (pectin and hemicellulose) that affects turgor and fruit water status (Atkinson et al., 2012). This process is regulated by ethylene, activating softening-associated enzymes such as polygalacturonase (Rupasinghe et al., 2000). 


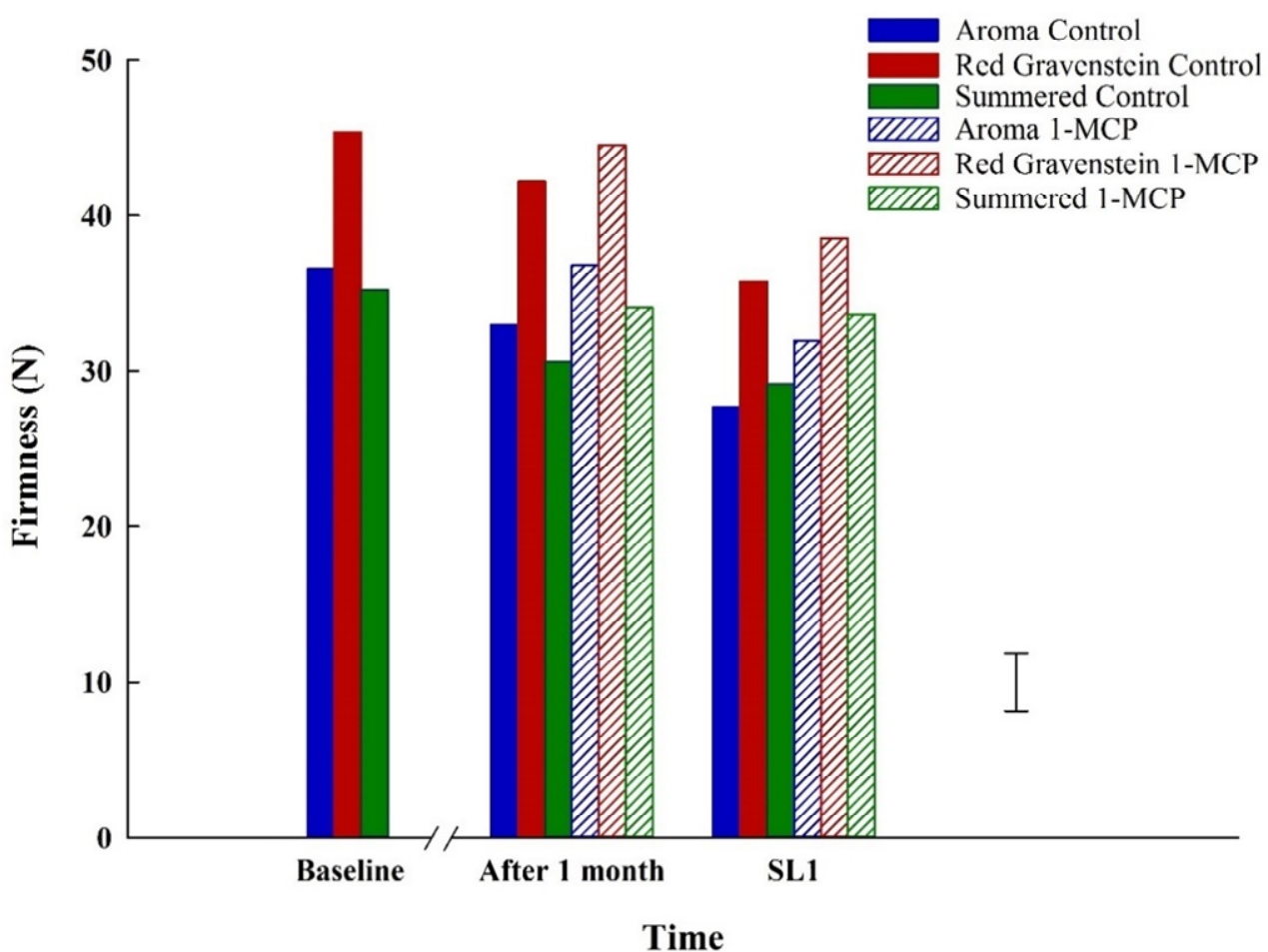

Figure 1. Firmness (N) of 'Aroma', 'Red Gravenstein' and 'Summered' apples subjected to Control (non-treated) and 1-MCP $\left(0.625 \mu \mathrm{L} \mathrm{L}^{-1}, 24 \mathrm{~h}, 0^{\circ} \mathrm{C}\right)$ is shown at day 0 (Baseline), after 1 month of cold storage (After 1 month), and after 5 days of room temperature storage, simulating home shelf life (SL1). Bars represent means of three replicates $(\mathrm{n}=10)$. $\mathrm{LSD}_{\text {treatment* time point }}$ is shown.

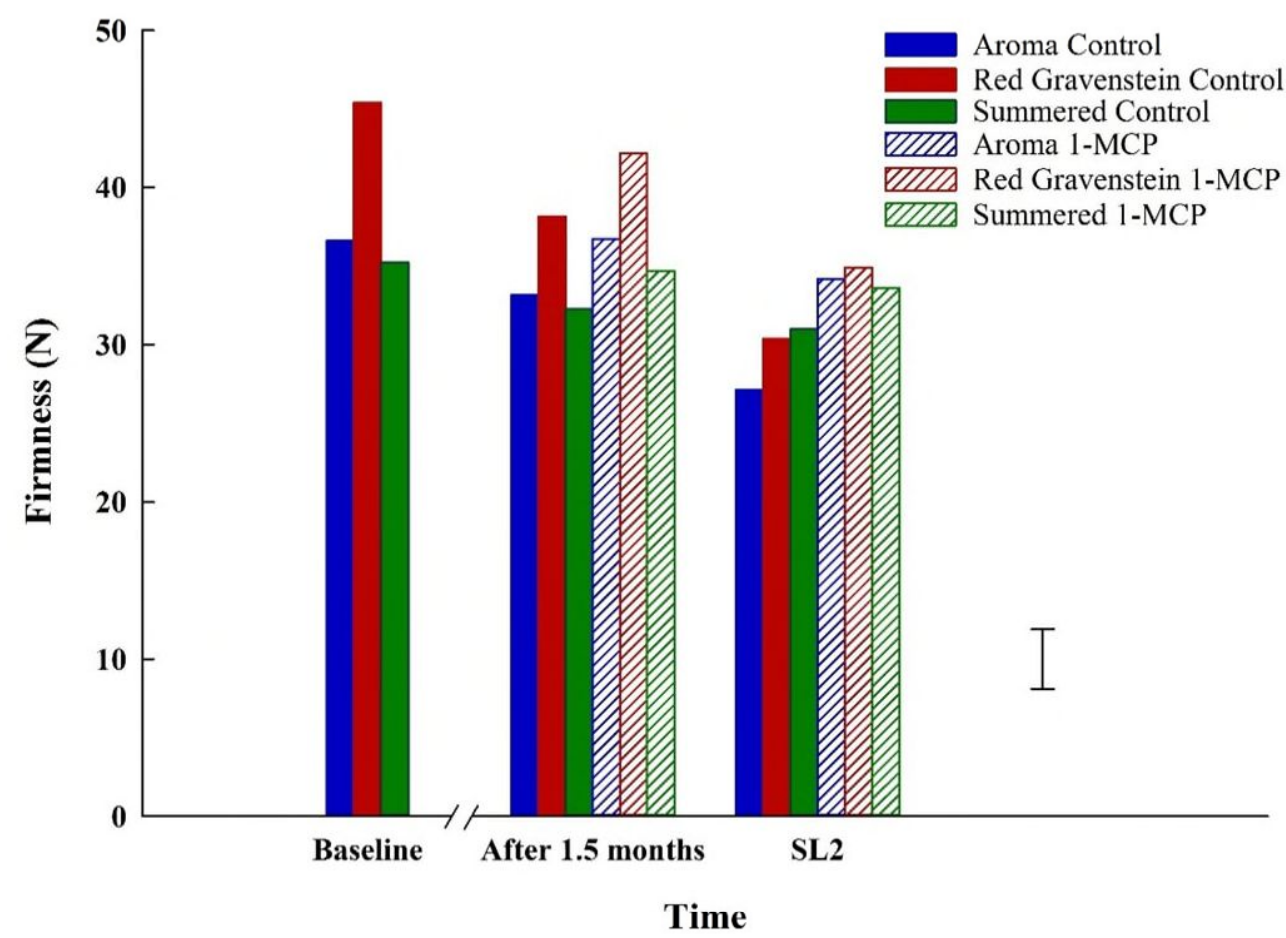

Figure 2. Firmness (N) of 'Aroma', 'Red Gravenstein' and 'Summered' apples subjected to Control (non-treated) and 1-MCP $\left(0.625 \mu \mathrm{L} \mathrm{L}^{-1}, 24 \mathrm{~h}, 0^{\circ} \mathrm{C}\right)$ is shown at day 0 (Baseline), after 1.5 months of cold storage (After 1.5 months), and after 5 days of room temperature storage, simulating home shelf life (SL2). Bars represent means of three replicates $(n=10)$. $\mathrm{LSD}_{\text {treatment* time point }}$ is shown. 
1-MCP binds to ethylene receptors, supressing ethylene-related responses. The interaction of 1-MCP with the apple ethylene receptors would likely have prevented loss of firmness in 1MCP treated fruit compared to control apples, which lost an average of $10 \%$ after one month of cold storage and $12.85 \%$ after 1.5 months.

Temperature is an essential factor determining fresh produce postharvest quality (Paull, 1999). However, fruit is often exposed to non-optimal temperatures during transport, distribution, retail, and household storage (Johnston et al., 2001), severely affecting quality. This can result in rejections, impacting on food waste. In the case of apples, $0-3^{\circ} \mathrm{C}$ is the optimal temperature range, depending on the cv. In order to simulate retailer and shelf life, apples were exposed to room temperature $\left(\sim 20-25^{\circ} \mathrm{C}\right)$ after cold storage. We speculated that this increase in temperature stimulated greater ethylene production (Gwanpua et al., 2017), which meant a reduction of firmness (Figures 1 and 2). The temperature impact was greater in control fruit than 1-MCP apples as control lost 12.46 and 16\% more firmness than 1-MCP fruit in SL1 (1 month) and SL2 (1.5 months), respectively. With respect to the two supply chain scenarios considered, 'Aroma' and 'Red Gravenstein' apples had a better firmness score when stored for 1 month, while 'Summered' fruit had a better response when stored for 1.5 months (Figures 1 and 2).

Colour is also an important parameter for decision-making when it comes to choosing a variety: it is classified as a 'search attribute' together with price. Background colour change from green to yellow is a sign of an active ripening process and therefore, indicating a loss of freshness. The background yellow/green colour of the apple peel is due to chlorophyll and carotenoids; the apple red colour is produced by anthocyanins and flavonols (Lancaster and Dougall, 1992). Anthocyanin biosynthesis is regulated by ethylene and external factors such as sun exposure, accumulating in the skin tissue during the ripening process (Dar et al., 2019). Characteristically, 'Red Gravenstein' apples were redder than 'Aroma' and 'Summered' cvs. on day 0 , showing a significantly lower $\mathrm{H}^{\circ}$. After one month of cold storage, fruit treated to 1MCP treatment did not change their initial colour, while control conditions reduced $\mathrm{H}^{\circ}$ level in 23.53, 9.70, and 41.12\% for 'Aroma', 'Red Gravenstein', and 'Summered' apples, respectively. This meant an increase in skin reddening, reducing the fresh appearance of the fruit and was consistent with other studies where the loss of greenness of the background colour was inhibited by 1-MCP (Saftner et al., 2003; Zanella, 2003). After 1.5 months of cold storage, control fruit reduced their $\mathrm{H}^{\circ}$ values on average $31 \%$, which implied a darkening in the skin colour (Figure 4), while no significant differences where shown by 1-MCP treated apples. The increase of temperature in the shelf life period affected colour development. All fruit presented a decrease of the $\mathrm{H}^{\circ}$ values, especially those stored under control conditions (Figures 3 and 4). This result agreed with other studies which showed that storage temperature was involved in triggering senescence and ripening during storage (Lee et al., 2016; Mir et al., 2001). 


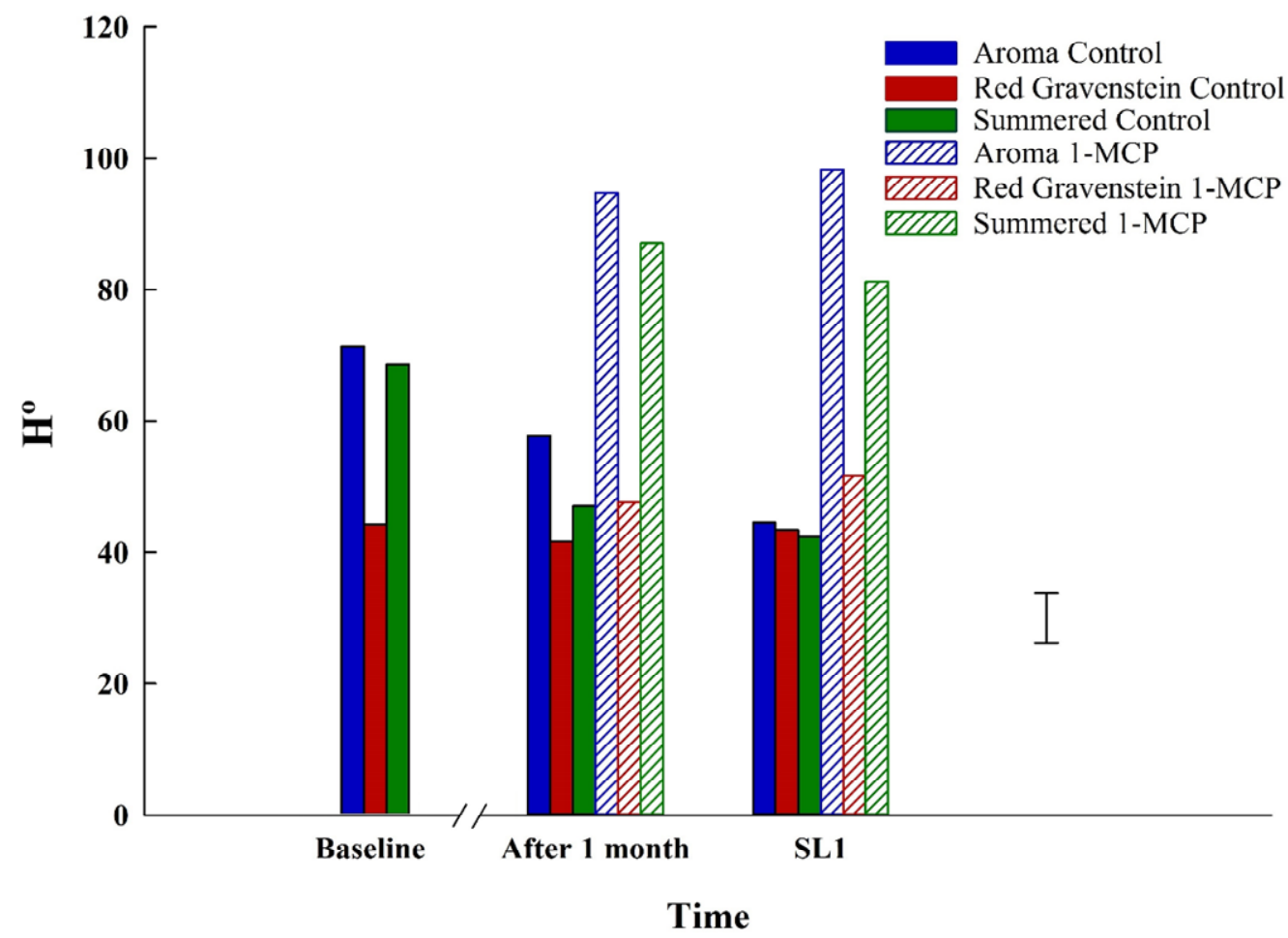

Figure 3. Hue angle $\left(\mathrm{H}^{\circ}\right)$ of 'Aroma', 'Red Gravenstein' and 'Summered' apples subjected to Control (nontreated) and 1-MCP $\left(0.625 \mu \mathrm{L} \mathrm{L}^{-1}, 24 \mathrm{~h}, 0{ }^{\circ} \mathrm{C}\right)$ is shown at day 0 (Baseline), after 1 month of cold storage (After 1 month), and after 5 days of room temperature storage, simulating home shelf life (SL1). Bars represent means of three replicates $(\mathrm{n}=10)$. $\mathrm{LSD}_{\text {treatment }} * \mathrm{cv}$ is shown.

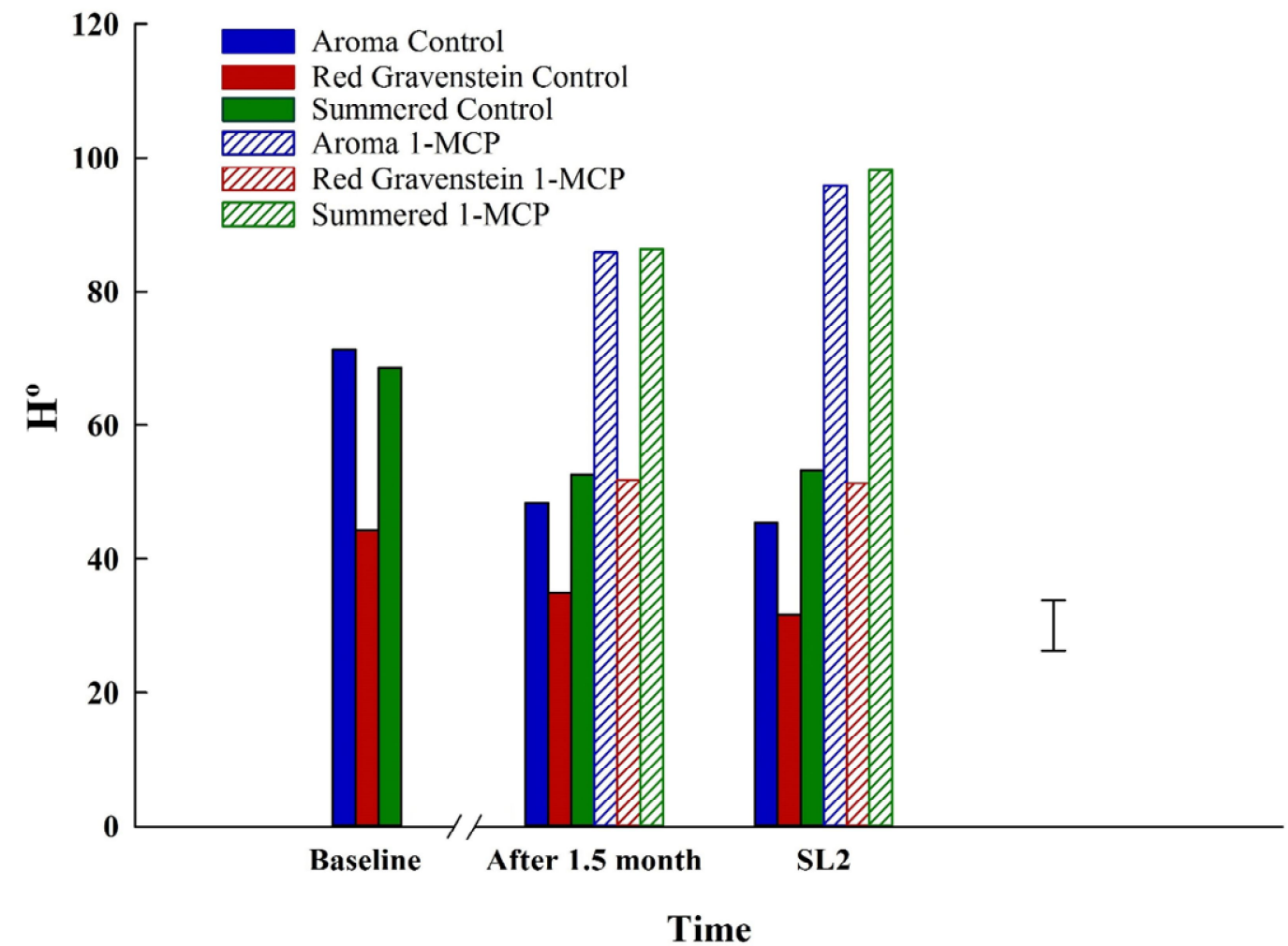

Figure 4. Hue angle $\left(\mathrm{H}^{\circ}\right)$ of 'Aroma', 'Red Gravenstein' and 'Summered' apples subjected to Control (nontreated) and 1-MCP $\left(0.625 \mu \mathrm{L} \mathrm{L}^{-1}, 24 \mathrm{~h}, 0{ }^{\circ} \mathrm{C}\right)$ is shown at day 0 (Baseline), after 1 month of cold storage (After 1.5 months), and after 5 days of room temperature storage, simulating home shelf life (SL2). Bars represent means of three replicates $(n=10)$. LSD treatment cv is shown. 
Consumers choose an apple cv. based on its firmness and appearance, but their decision to repurchase depends on their satisfaction to its organoleptic characteristics (Harker et al., 2003). Sweetness is one of the drivers for consumer preference and TSS is used to estimate this trait (Aprea et al., 2017). The accumulation of TSS during fruit development determines sweetness (Li et al., 2018) and is used as an indicator for decision-making on selecting an appropriate picking date. In this work, 'Summered' apples showed the highest TSS at harvest when compared to 'Aroma' and 'Red Gravenstein' cvs. (13.32 $\pm 0.15^{\circ}$ Brix vs. $11.12 \pm 0.19$ and $12.52 \pm 0.20^{\circ}$ Brix, respectively). TSS content generally changes with fruit development, peaking at maturity (Desnoues et al., 2014). However, no differences were found after 1 and 1.5 months of cold storage with respect to the initial values, for both control and 1-MCP treatments (data not shown).

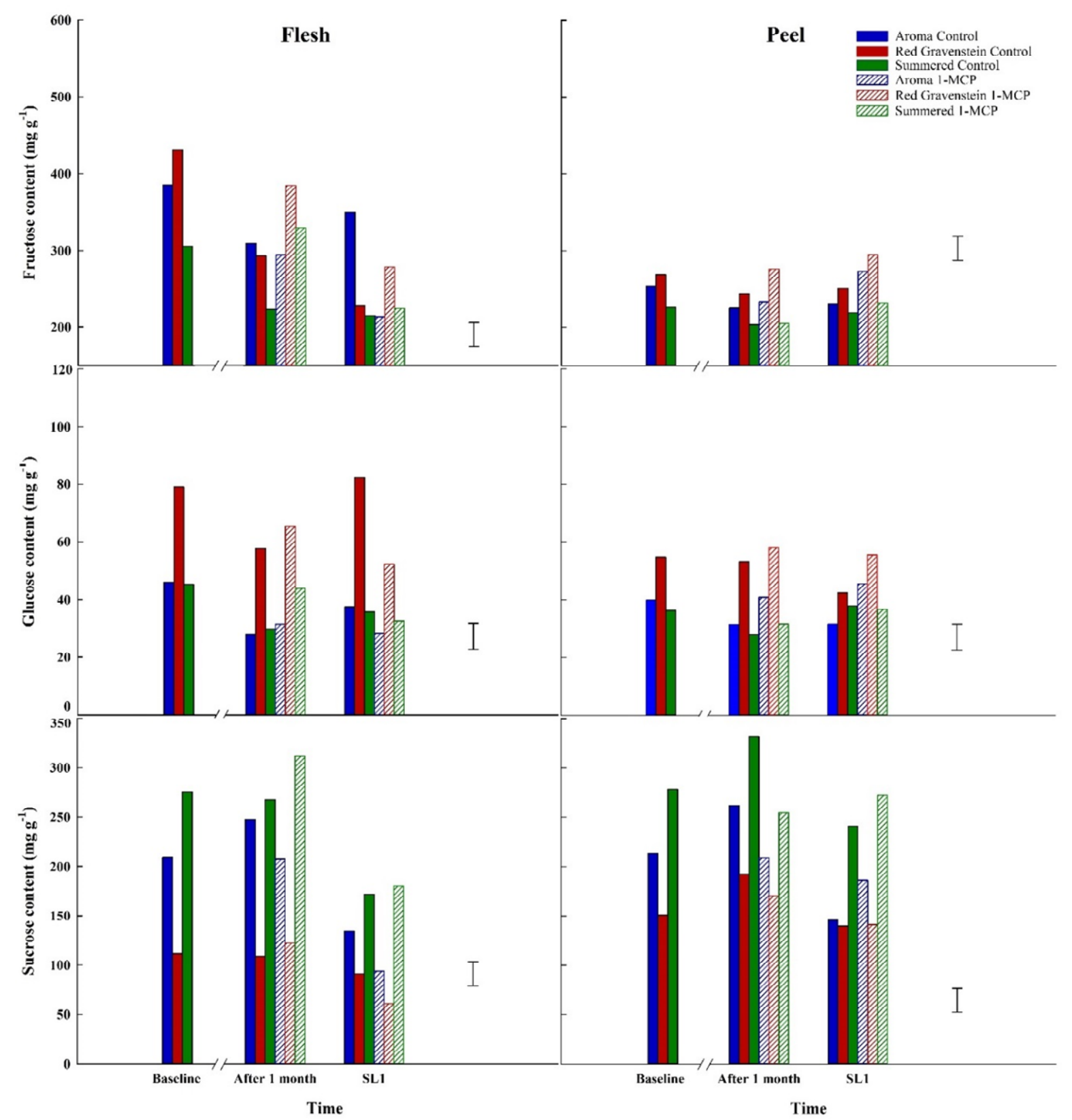

Figure 5. Reducing sugars (Fructose, Glucose, Sucrose; $\mathrm{mg} \mathrm{g}^{-1}$ ) of 'Aroma', 'Red Gravenstein' and 'Summered' apples subjected to Control (non-treated) and 1-MCP $\left(0.625 \mu \mathrm{L} \mathrm{L}^{-1}, 24 \mathrm{~h}, 0{ }^{\circ} \mathrm{C}\right)$ is shown at day 0 (Baseline), after 1 month of cold storage (After 1 month), and after 5 days of room temperature storage, simulating home shelf life (SL2). Bars represent means of three replicates $(n=3)$. LSD time point $*$ cv is shown. 


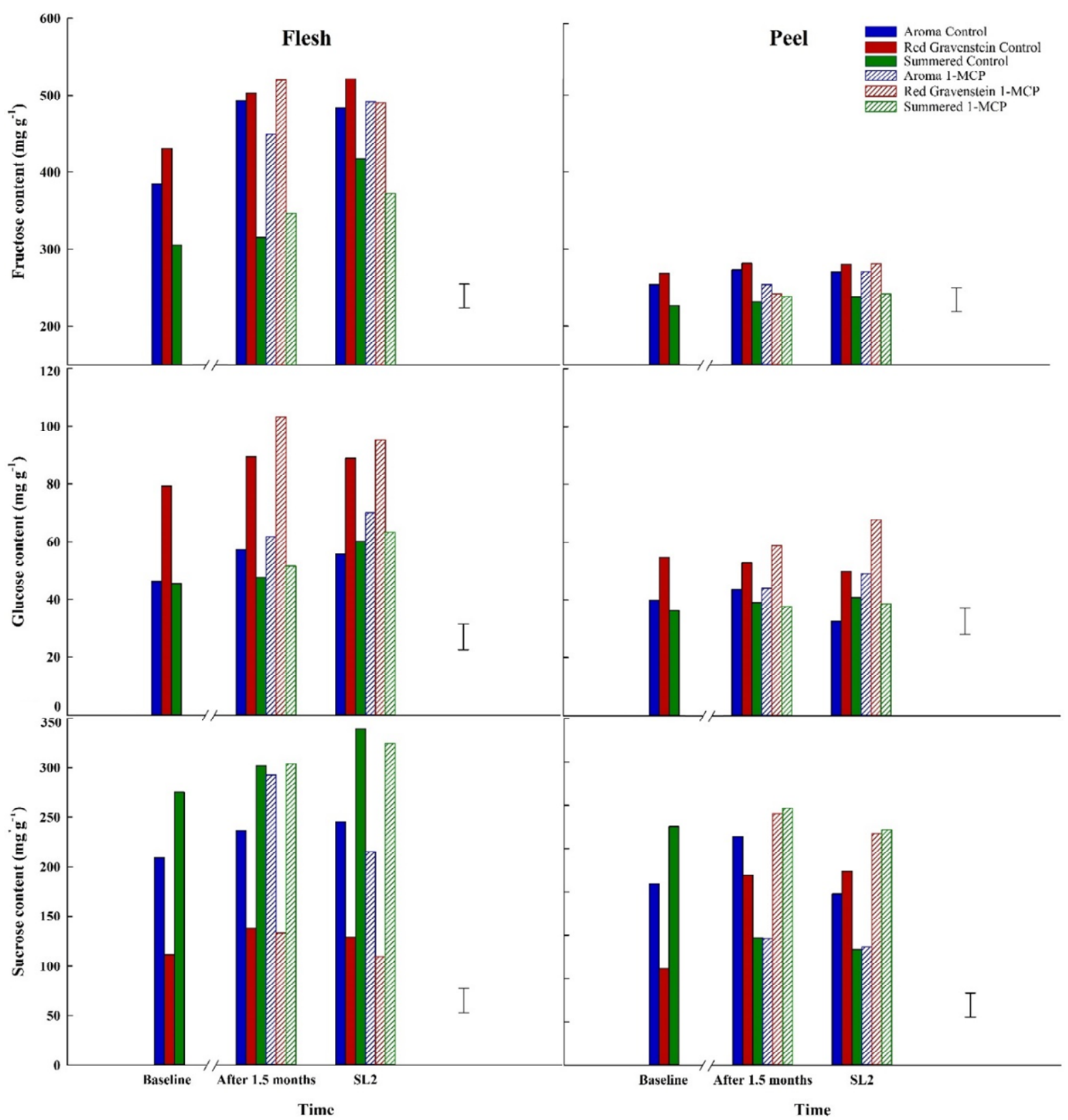

Figure 6. Reducing sugars (Fructose, Glucose, Sucrose; $\mathrm{mg} \mathrm{g}^{-1}$ ) of 'Aroma', 'Red Gravenstein' and 'Summered' apples subjected to Control (non-treated) and 1-MCP $\left(0.625 \mu \mathrm{L} \mathrm{L}^{-1}, 24 \mathrm{~h}, 0{ }^{\circ} \mathrm{C}\right.$ ) is shown at day 0 (Baseline), after 1.5 months of cold storage (After 1.5 months), and after 5 days of room temperature storage, simulating home shelf life (SL2). Bars represent means of three replicates $(n=3)$. LSD time point $*$ cv is shown.

It has been reported that 1-MCP can increase, decrease, or not affect the TSS depending on the apple cv. (Watkins, 2000), which was also observed in this study. We hypothesised that an earlier harvest date could increase the efficacy of 1-MCP, as the number of ethylene receptors would be lower and therefore, easier to control with a 1-MCP treatment (Tatsuki et al., 2007). In the case of non-structural carbohydrates, fructose was the main sugar for all cvs. (Figures 5 and 6), in agreement with Li et al. (2012). 'Red Gravenstein' showed the highest fructose content at harvest when compared to 'Aroma' and 'Summered' cvs. This result indicated that 'Red Gravenstein' apples were sweeter than 'Aroma' and 'Summered' as fructose directly impacts on sweetness perception, being almost twice as sweet as glucose (Biester et al., 1925; 
Desnoues et al., 2014). Fructose accumulated more in the flesh than skin. In both scenarios, both control and 1-MCP apples showed a slight decrease in fructose concentration, with a greater increase under control conditions (Figures 5 and 6).

In apples, a small portion of fructose is converted into starch; in general, it accumulates in the vacuoles of the tissue cells with maturation (Aprea et al., 2017). Correspondingly, fructose content is higher than glucose content as confirmed by this work. Glucose is generally incorporated into starch, showing lower concentrations in fruit tissue (Yamaki and Ino, 1992). At harvest, 'Red Gravenstein' apples had the highest glucose concentration when compared to 'Aroma' and 'Summered' cvs. (for flesh: $79.30 \pm 2.21 \mathrm{mg} \mathrm{g}^{-1} \mathrm{dw}$ vs. $46.27 \pm 0.77$ and $45.62 \pm$ $0.22 \mathrm{mg} \mathrm{g}^{-1} \mathrm{dw}$, respectively; for skin: $54.82 \pm 1.12 \mathrm{mg} \mathrm{g}^{-1} \mathrm{dw}$ vs. $39.87 \pm 0.17$ and $36.30 \pm$ $0.77 \mathrm{mg} \mathrm{g}^{-1} \mathrm{dw}$, respectively). All samples presented a slight decrease during storage and shelf life (Figures 5 and 6). In the case of sucrose, 'Summered' apples showed the highest content when compared to 'Aroma' and 'Red Gravenstein' cvs. (for flesh: $275.20 \pm 4.84 \mathrm{mg} \mathrm{g}^{-1} \mathrm{dw}$ vs. $209.20 \pm 1.09$ and $111.70 \pm 7.88 \mathrm{mg} \mathrm{g}^{-1} \mathrm{dw}$, respectively; for skin: $278 \pm 3.27 \mathrm{mg} \mathrm{g}^{-1} \mathrm{dw}$ vs. $213.30 \pm 1.64$ and $150.81 \pm 3.27 \mathrm{mg} \mathrm{g}^{-1} \mathrm{dw}$, respectively). Sucrose content showed a subtle decreasing trend in flesh in scenario 1 while maintaining the initial values in scenario 2 (Figures 5 and 6). According to the behaviour patterns of individual sugars with respect to storage and shelf life time, sucrose decreased for most lines, while fructose increased for 'Aroma' control samples, confirming the theory of sucrose hydrolysis. During postharvest period, sucrose suffers an irreversible hydrolysis into fructose and glucose, catalysed by the enzyme invertase (Kleczkowski et al., 2010; Tong et al., 2018). 1-MCP treatment had no significant effect on glucose and sucrose contents (Figures 5 and 6). However, fruit exposed to 1-MCP showed a lower increase in fructose content $(\mathrm{p}<0.05)$. This indicated a slower ripening as sugar metabolism is linked to plant processes, regulating plant development (Li et al., 2012). In this sense, the effect of 1-MCP on ripening was observed in both the quality results and the biochemical compounds.

The ratios between the different individual sugars are also involved in the apple fruit taste; in particular, the ratio fructose-to-glucose (Desnoues et al., 2014). 'Red Gravenstein' showed the highest fructose and glucose concentrations in both peel and flesh; it was the cv. which showed the lowest fructose-to-glucose ratio when compared to 'Aroma' and 'Summered' cvs. (for flesh: 7.63 vs. 11.59 and 10.18, respectively; for skin: 7.10 vs. 9.24 and 9.74, respectively). These results positively correlated with the TSS measurements. Fructoseto-glucose ratio decreased over time in all cases, especially during shelf life. For example, 'Aroma' apples stored under control conditions reduced their fructose-to-sucrose ratio by $9 \%$ after cold storage, while during shelf life the ratio decreased $22.70 \%$ with respect to the initial values. Despite the decrease, the cvs. had a much higher fructose-to-glucose ratio than the apple cvs. currently available in many supermarkets (Granny Smith: 2.1; Pink Lady: 3.4; Golden Delicious: 2.6; Royal Gala: 3.0; Fuji: 2.3; Hermann and Bordewick-Dell, 2018).

\section{CONCLUSION}

The data shown in this work has confirmed that 1-MCP postharvest treatment has a promising potential for maintenance of apple cvs. grown in Norway during cold storage. Its application is a good alternative to CA methods. Further research is needed to test if an earlier harvest could improve the efficacy of 1-MCP in apples grown in Norway.

\section{ACKNOWLEDGEMENTS}

The authors thank AgrofreshTM for supplying the 1-MCP solution, and Hardanger Fjordfrukt SA for providing the plant material. 


\section{DECLARATION OF CONFLICTING INTERESTS}

The authors declared no potential conflicts of interest with respect to the research, authorship, and/or publication of this article.

\section{FUNDING}

The authors received no financial support for the research, authorship, and/or publication of this article.

\section{ORCID ID}

N Falagán https://orcid.org/0000-0002-7672-9565

LA Terry https://orcid.org/0000-0001-5677-023X

\section{REFERENCES}

Almeida DPF, Carvalho R and Dupille E. (2016). Efficacy of 1-methylcyclopropene on the mitigation of storage disorders of 'Rocha' pear under normal refrigerated and controlled atmospheres. Food Science and Technology International 22(5): 399-409.

Anastasiadi M, Mohareb F, Redfern SP, Berry M, Simmonds MSJ and Terry LA. (2017). Biochemical profile of heritage and modern apple cultivars and application of machine learning methods to predict usage, age, and harvest season. Journal of Agricultural and Food Chemistry 65: 5339-5356.

Aprea E, Charles M, Endrizzi I, Corollaro ML, Betta E, Biasioli F, et al. (2017). Sweet taste in apple: The role of sorbitol, individual sugars, organic acids and volatile compounds. Scientific Reports 7: 44950.

Atkinson RG, Sutherland PW, Johnston SL, Gunaseelan K, Hallett IC, Mitra D, et al. (2012). Down-regulation of POLYGALACTURONASE1 alters firmness, tensile strength and water loss in apple (Malus x domestica) fruit. BMC Plant Biology 12: 129.

Biester A, Wood MW and Stone Wahlin C. (1925). Carbohydrate studies. I. Relative sweetness of pure sugars. American Journal of Physiology 73: 387-400. Blankenship SM and Dole JM. (2003). 1-Methylcyclopropene: A review. Postharvest Biology and Technology 28: 1-25.

Brizzolara S, Santucci C, Tenori L, Hertog MLATM, Nicolai B, Stürz S, et al. (2017). A metabolomics approach to elucidate apple fruit responses to static and dynamic controlled atmosphere storage. Postharvest Biology and Technology 127: 76-87.

Chen B, Mao J, Huang B, Mi B, Liu Y, Hu Z, et al. (2017). Effect of bagging and time of harvest on fruit quality of 'Red Fuji' apple in high altitude area in China. Fruits 72(1): 36-46.

Chope GA, Terry LA and White PJ. (2007). The effect of 1-methylcyclopropene (1-MCP) on the physical and biochemical characteristics of onion cv. SS1 bulbs during storage. Postharvest Biology and Technology 44: 131-140.

Dar JA, Wani AA, Ahmed M, Nazir R, Zargar SM and Javaid K. (2019). Peel colour in apple (Malus $x$ domestica Borkh.): An economic quality parameter in fruit market. Scientia Horticulturae 244: 50-60. 
Desnoues E, Gibon Y, Baldazzi V, Signoret V, Génard M and Quilot-Turion B. (2014). Profiling sugar metabolism during fruit development in a peach progeny with different fructose-to-glucose ratios. BMC Plant Biology 1: 336.

Downes K and Terry LA. (2010). A new acetonitrile-free mobile phase method for LC-ELSD quantification of fructo oligosaccharides in onion (Allium cepa L.). Talanta 82(1): 118-124.

Duarte C, Guerra M, Daniel P, Camelo AL and Yommi A. (2009). Quality changes of highbush blueberries fruit stored in CA with different CO2 levels. Journal of Food Science 74(4): 154159.

Falagán N and Terry LA. (2018). Recent advances in controlled and modified atmosphere of fresh produce. Johnson Matthey Technology Reviews 62(1): 107-117.

FAOSTAT. (2018). FAO Statistics. Rome: Food and Agriculture Organization of the United Nations. FDA. (2004). 1-Methylcyclopropene (PC Code 224459).

Golding JB and Singh SP. (2017). Use of 1-MCP in the Storage Life Extension of Fruit. Ourimbah: Department of Primary Industries.

Gwanpua SG, Verlinden BE, Hertog MLATM, Nicolai BM and Geeraerd AH. (2017). A mechanistic modelling approach to understand 1-MCP inhibition of ethylene action and quality changes during ripening of apples. Journal of the Science of Food and Agriculture 97(11): 3802-3813.

Harker FR, White A, Freeth B, Gunson FA and Triggs CM. (2003). Simultaneous instrumental measurement of firmness and juiciness of apple tissue discs. Journal of Texture Studies 34(3): 271-285.

Hermann K and Bordewick-Dell U. (2018). Fructose in different apple varieties. Ernaehrungs Umschau International 3: 48-52.

Hoehn E, Gasser F, Guggenbühl B and Künsch U. (2003). Efficacy of instrumental measurements for determination of minimum requirements of firmness, soluble solids, and acidity of several apple varieties in comparison to consumer expectations. Postharvest Biology and Technology 27(1): 27-37.

Johnston JA, Hewett EW, Hertog MLATM and Harker FR. (2001). Temperature induces differential softening responses in apple cultivars. Postharvest Biology and Technology 23(3): 185-196.

Kart MCO and Demircan V. (2015). Analysis of investment cost of apple cold storage facilities. Custos e Agronegocio 11(1): 53-70.

Kleczkowski LA, Kunz S and Wilczynska M. (2010). Mechanisms of UDP-glucose synthesis in plants. Critical Reviews in Plant Sciences 29: 191-203.

Lancaster JE and Dougall DK. (1992). Regulation of skin color in apples. Critical Reviews in Plant Sciences 10(6): 487-502. 
Lee J, Mattheis JP and Rudell DR. (2016). Storage temperature and 1-methylcyclopropene treatment affect storage disorders and physiological attributes of 'Royal Gala' apples. Horticultural Science 51(1): 84-93.

Li M, Feng F and Cheng L. (2012). Expression patterns of genes involved in sugar metabolism and accumulation during apple fruit development. PLoS One 7(3): e33055.

Li M, Li P, Ma F, Dandekar AM and Cheng L. (2018). Sugar metabolism and accumulation in the fruit of transgenic apple trees with decreased sorbitol synthesis. Horticultural Research 5: 60 .

Liguori G, Farina V, Corona O, Mazzaglia A, Barone E and Inglese P. (2017). Effects of 1MCP on postharvest quality and internal browning of white-flesh loquat fruit during cold storage. Fruits 72(2): 67-73.

Meberg KR, Haffner K and Rosenfeld HJ. (2000). Storage and shelf-life of apples grown in Norway I. Effects of controlled atmosphere storage on aroma. GartenbauwissenschaftMunchen 65(1): 9-16.

Mir NA, Curell E, Khan N, Whitaker M and Beaudry RM. (2001). Harvest maturity, storage temperature, and 1- MCP application frequency alter firmness retention and chlorophyll fluorescence of 'Redchief Delicious' apples. Journal of the American Society for Horticultural Science 126: 618-624.

Moran ER and McManus P. (2005). Firmness retention, and prevention of coreline browning and senescence in 'Macoun' apples with 1-methylcyclopropene. Journal of the American Society for Horticultural Science 40(1): 161-163.

Paull R. (1999). Effect of temperature and relative humidity on fresh commodity quality. Postharvest Biology and Technology 15(3): 263-277.

Pre-Aymard C, Fallik E, Weksler A and Lurie S. (2005). Sensory analysis and instrumental measurements of Falaga'n and Terry 9 'Anna' apples treated with 1-methylcyclopropene. Postharvest Biology and Technology 36: 135-142.

Rademacher W. (2015). Plant growth regulators: Backgrounds and uses in plant production. Journal of Plant Regulation 34: 845-872.

Rupasinghe HPV, Murr DP, Paliyath G and Skog L. (2000). Inhibitory effect of 1-MCP on ripening and superficial scald development in 'McIntosh' and 'Delicious' apples. The Journal of Horticultural Science and Biotechnology 75(3): 271-276.

Saftner RA, Abbott JA, Conway WS and Barden CL. (2003). Effects of 1-methylcyclopropene and heat treatments on ripening and postharvest decay in 'Golden Delicious' apples. Journal of the American Society for Horticultural Science 128: 120-127.

Schwallier P. (2012). Checking Apple Maturity: What to Look for. Michigan State University Extension. Available at: http://www.msue.msu.edu (accessed 19 February 2019). 
Silvestri C, Cirilli M, Zecchini M, Muleo R and Ruggieri A. (2018). Consumer acceptance of the new red-fleshed apple variety. Journal of Food Products Marketing 24(1): 1-21.

Sisler EC and Serek M. (1997). Inhibitors of ethylene responses in plants at the receptor level: Recent developments. Physiologia Plantarum 100: 577-582.

Tatsuki M, Endo A and Ohkawa H. (2007). Influence of time from harvest to 1-MCP treatment on apple fruit quality and expression of genes for ethylene biosynthesis enzymes and ethylene receptors. Postharvest Biology and Technology 43(1): 28-35.

Thewes FR, Brackmann A, de Oliveira Anese R, Bronzatto ES, Schultz EE and Wagner R. (2017). Dynamic controlled atmosphere storage suppresses metabolism and enhances volatile concentrations of 'Galaxy' apple harvested at three maturity stages. Postharvest Biology and Technology 127: 1-13.

Tong XL, Wang ZY, Ma BQ, Zhang CX, Zhu LC, Ma F, et al. (2018). Structure and expression analysis of the sucrose synthase gene family in apple. Journal of Integrative Agriculture 17: $847-856$.

Watkins CB. (2000). Responses to horticultural commodities to high carbon dioxide as related to modified atmosphere packaging. HortTechnology 10: 501-506.

Watkins CB. (2003). Principles and practices of postharvest handling and stress. In: Ferree DC and Warrington IJ (eds) Apple: Botany, Production and Use. Wallingford: CAB International, pp. 85-614.

Watkins CB. (2006). The use of 1-methylcyclopropene (1- MCP) on fruits and vegetables. Biotechnology Advances 24(4): 389-409.

Watkins CB and Nock JF. (2012). Rapid 1-methylcyclopropene (1-MCP) treatment and delayed controlled atmosphere storage of apples. Postharvest Biology and Technology 69: 2431.

Watkins CB, Nock JF and Whitaker BD. (2000). Responses of early, mid and late season apple cultivars to postharvest application of 1-methylcyclopropene (1-MCP) under air and controlled atmosphere storage conditions. Postharvest Biology and Technology 19(1): 17-32.

Yamaki S and Ino M. (1992). Alteration of cellular compartmentation and membrane permeability to sugars in immature and mature apple fruit. Journal of the American Society for Horticultural Science 117: 951-954.

Zanella A. (2003). Control of apple superficial scald and ripening - A comparison between 1methylcyclopropene and diphenylamine postharvest treatments, initial low oxygen stress and ultra-low oxygen storage. Postharvest Biology and Technology 27: 69-78. 